\title{
Taxonomic identification of appendicularians collected in the epipelagic waters off northern Chile (Tunicata, Appendicularia)
}

\author{
Identificación taxonómica de las apendicularias capturadas en aguas epipelágicas de \\ la zona norte de Chile (Tunicata, Appendicularia)
}

\author{
GUILLERMO ARAVENA ${ }^{1} \&$ SERGIO PALMA ${ }^{2}$ \\ Escuela de Ciencias del Mar, Universidad Católica de Valparaíso, Casilla 1020 Valparaíso, Chile; \\ e-mail: ${ }^{1}$ g_aravena@yahoo.com; ${ }^{2}$ spalma@ucv.cl
}

\begin{abstract}
This work provides a first taxonomic description of appendicularians collected during September and August of 1995 in the north coast of Chile $\left(18^{\circ} 23^{\prime}-31^{\circ} 00^{\prime} \mathrm{S}\right)$. Fifteen species were identified. They belong to the families Oikopleuridae (Oikopleura longicauda, O. cophocerca, O. dioica, O. rufescens, O. fusiformis, O. albicans, O. gracilis and Megalocercus abyssorum), and Fritillariidae (Fritillaria pellucida typica, F. pellucida omani, F. haplostoma F. tenella, $F$. formica digitata, $F$. venusta and $F$. fraudax). All the species are first records for waters of northern Chile, thus broadening their previous distribution in the southeast Pacific. The most abundant species were Oikopleura longicauda (56.1\%), O. gracilis (10.4\%), Fritillaria pellucida typica $(6.7 \%)$; O. albicans $(5.0 \%)$; F. pellucida omani (4.7\%); $O$. cophocerca $(4.4 \%)$ and $F$. venusta $(4.1 \%)$, whereas the eight remaining species, constituted $8.6 \%$ of the total appendicularians collected.
\end{abstract}

Key words: Appendicularia, larvaceans, taxonomy, new record, northern Chile.

\section{RESUMEN}

El presente trabajo proporciona una primera descripción taxonómica de las apendicularias colectadas durante septiembre y agosto de 1995 en la costa norte de Chile (18 $\left.23^{\prime}-31^{\circ} 00^{\prime} \mathrm{S}\right)$. Se identificaron 15 especies de apendicularias pertenecientes a las familias Oikopleuridae (Oikopleura longicauda, O. cophocerca, O. dioica, O. rufescens, O. fusiformis, $O$. albicans, $O$. gracilis and Megalocercus abyssorum) y Fritillariidae (Fritillaria pellucida typica, $F$. pellucida omani, $F$. haplostoma $F$. tenella, F. formica digitata, $F$. venusta and $F$. fraudax). Todas las especies identificadas se registran por primera vez para aguas del norte de Chile y se amplía su distribución en esta área del Pacífico Suroriental. Las especies más abundantes fueron Oikopleura longicauda (56,1 \%), O. gracilis (10,4 \%), Fritillaria pellucida typica $(6,7 \%) ; O$. albicans $(5,0 \%) ; F$. pellucida omani $(4,7 \%) ; O$. cophocerca $(4,4 \%)$ y $F$. venusta $(4,1 \%)$, mientras que las ocho especies restantes constituyeron el 8,6 \% del total de apendicularias colectadas.

Palabras clave: Apendicularia, larváceos, taxonomía, nuevos registros, norte de Chile.

\section{INTRODUCTION}

The southeast margins of the ocean are zones of high marine productivity because of oceanographic conditions associated with cold currents flowing parallel to the coast (Cushing 1969, Barber et al. 1971, Mann \& Lazier 1996). Among them, the Humboldt Current System is considered as one of the most productive of the world (Barber \& Chávez 1983). The primary production is channeled through the trophic web, sustaining the high production in waters off the northern coast of Chile and southern Peru.

The marine zooplankton of Chilean waters poses a wide perspective of study, because of the persistent lack of taxonomic knowledge of several groups that constitute this community. In spite of the valuable contributions made in past decades, there are several deficiencies in the taxonomy of groups, such as the appendicularians, polychaetes and microcrustaceans (amphipods, ostracods and cladocerans). Thus, the knowledge, not only about plankton biodiversity, but also on the patterns of biogeographic distribution of several species is limited.

Appendicularians are one of the most common groups in zooplankton samples, widely distributed in all oceans (Esnal 1981). Most of the studies have been carry out on species from the Mediterranean Sea, Indian, Antarctic, and Atlantic oceans (Lohmann 1928, Fenaux 1967, 1969a, 1969b, 1993, Fenaux \& Godeaux 1970, Esnal 
1972, 1979, 1981, 1999, Esnal \& Castro 1977, Acuña 1994), Caribbean Sea (Tokioka \& Suárez-Caabro 1956, Flores-Coto 1965, 1974, Alldredge 1976, Castellanos \& Gasca 1998) and Red Sea (Fenaux \& Godeaux 1970). However, the waters of the Pacific Ocean have been poorly studied, existing for the northeast Pacific only the records of Tokioka $(1955,1958)$ and the record of nine species belonging to the family Oikopleuridae in the southeast Pacific coast of Perú (Fenaux 1968). Recently, Grünewald et al. (1998) determined the spatial distribution of appendicularians in central-south Chile, pointing out that all individuals belong to the genus Oikopleura, without identifying the species collected.

In the past decades, the ecological function of the appendicularians in the trophic web has been revealed (Esnal 1979). The importance of these filtering herbivores stands in the active and selective grazing exerted upon the very small particles of pico- and nanoplankton, thus becoming a rich source of available food for other taxa. The organisms feed by means of a complex mucous structure named house, which is secreted at intervals of 2 to $4 \mathrm{~h}$, reaching up to 16 houses per day (Barham 1979, Esnal 1999). These houses are rejected due to the accumulation of feces that clog the filters. This material serves for the retention of very small organic particles. It is used as a fixation substrate, or just as a rich energetic food for other zooplankters, such as medusae, siphonophores, copepods, chaetognaths, euphausiids, decapods and polychaete larvae (Esnal 1981, Ohtsuka \& Kubo 1991).

Also, the appendicularians constitutes an important part of the diet of economically important fishes, like the herring, Clupea harengus, the Pacific sardine, Sardinops sagax, and the Argentinean anchovy, Engraulis anchoita (Cailliet \& Ebeling 1990, Capitanio et al. 1997). This paper contributes to the taxonomic knowledge of appendicularians from Chilean waters of this area of the southeast Pacific Ocean.

\section{MATERIAL AND METHODS}

Plankton samples were obtained during the development of the project FIP95-03 Hydroacoustic resource evaluation of anchovy, jack mackerel and sardine from regions I trough IV, conducted by the Fisheries Development Institute (IFOP). The cruise was performed off the northern zone of Chile, between Arica $\left(18^{\circ} 23^{\prime} \mathrm{S}\right)$ and Punta Talca $\left(31^{\circ} 00^{\prime} \mathrm{S}\right)$. The survey was conducted onboard the B/I Carlos Porter, during the winter season, between August 6 and September 16, 1995.
The sampling comprised 229 oceanographic stations placed at 1, 5, 10, 20, 40, 70 and $100 \mathrm{~nm}$ of the coast. Stations were distributed in 34 transects perpendicular to the coast, separated by $20 \mathrm{~nm}$ between Arica and Punta Amarilla (18 $23^{\circ}$ $\left.24^{\circ} 00^{\prime} \mathrm{S}\right)$, and every $25 \mathrm{~nm}$ between Punta Amarilla and Punta Talca $\left(24^{\circ} 00^{\prime}-31^{\circ} 00^{\prime}\right.$ S) (Fig. 1).

The samples were obtained from vertical tows from $100 \mathrm{~m}$ depth to surface. A WP-2 net of $57 \mathrm{~cm}$ diameter $\left(0.25 \mathrm{~m}^{2}\right.$ mouth opening $), 2.61-\mathrm{m}$ length and $297 \mu \mathrm{m}$ of mesh size was used. The trunk of most appendicularians measure more than 300 $\mu \mathrm{m}$, therefore the mesh size was considered adequate to retain adult specimens. It was equipped with OSK flowmeters to estimate the volume filtered. The material obtained was fixed with $5 \%$ formaldehyde in seawater, neutralized with sodium tetraborate. The taxonomic identification of the appendicularians was performed using morphological descriptions and species keys (Tokioka 1955, 1958, Tokioka \& Suárez-Caabro 1956, Fenaux 1967, 1968, 1993, Esnal 1981, 1999).

\section{RESULTS}

\section{General morphology}

The appendicularians are pelagic tunicates of the class Copelata, characterized by the conservation of the notochord during all their life span and the absence of an atrial cavity or cloaca. The body is comprised by the trunk $(<5 \mathrm{~mm})$, divided into three regions: pharingo-branchial, digestive and genital, and the tail (>5 mm). The mouth opens to the pharynx region through two branchial openings ending in two spiracles. The pharynx region has a short endostyle formed by long muscular cells. Some species have a pair of buccal glands near the anterior extreme of the endostyle. The stomach is slightly globular and can be divided into lobules; the intestine is more or less oval and the rectum ends in an anus opened ventrally or laterally.

With the exception of Oikopleura dioca, the appendicularians are hermaphrodites and the gonads occupy a relatively large part of the body in mature individuals, sometimes producing the curvature of the trunk of the animal. The length of the tail is three times the length of the body. The tail has a neural chord or notochord, covered by a well-developed musculature. On both sides of the tail there could be subchordal and amphichordal cells, which are absent in some species, depending on the family. 
The most frequently used morphological features for the taxonomic identification are: shape of the body and tail; presence or absence of prebuccal glands; shape of the spiracles; development of a caecum in the left lobule of the stomach; shape of the digestive apparatus; shape and disposition of the gonads; presence, number and disposition of the amphichordal and subchordal cells in the tail (Fenaux 1993).

In general, the shape of the trunk and the tail is used for the identification and taxonomic classification of the three families comprising this group: Oikopleuridae, Fritillariidae and Kowalevskiidae (Fig. 2 and 3). The appendi- cularians collected in the north zone were classified according to the criteria of Esnal (1981, 1999) and Fenaux (1993).

\section{Taxonomic classification}

Phylum Chordata

Subphylum Tunicata (Urochordata)

Class Appendicularia

Order Appendiculariae

Family Oikopleuridae. The body is ovoid with two branchial openings with ciliated rings connecting the pharyngeal cavity with the exterior

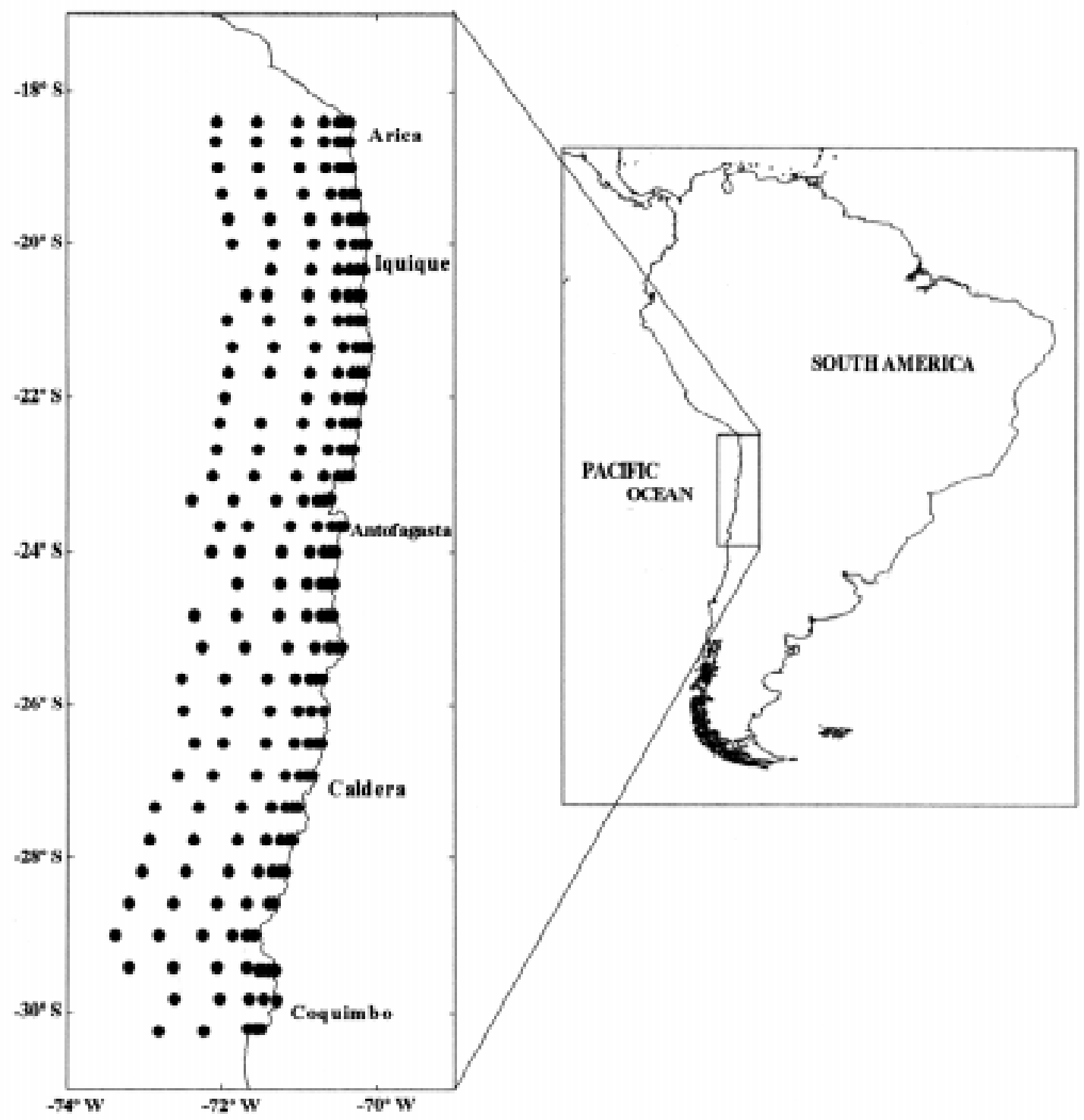

Fig. 1: Location of sampling stations in northern Chile (August and September 1995).

Ubicación de las estaciones oceanográficas en la zona norte de Chile (agosto y septiembre 1995). 
through tubular conduits, ending in the spiracle openings. The spiracles are generally placed at the level of the rectum. The stomach wall is composed of numerous small cells with one line of large cells. Fol's fibroblasts are placed on both side of the oikoplastic layer.

Subfamily Oikopleurinae. The mouth is situated forwards, with a lower lip. Endostyle elon- gated. Spiracles with a ciliated circular ring. Fol's fibroblasts are preceded by a line of giant cells (colloblasts). The oikoplastic layer extends reaching the anus.

Genus Oikopleura. The digestive tract is compact nucleus. Mouth with an inferior lip. Stomach covers the rear end of the intestine, laterally wide on the right side and lobed on the left side. The
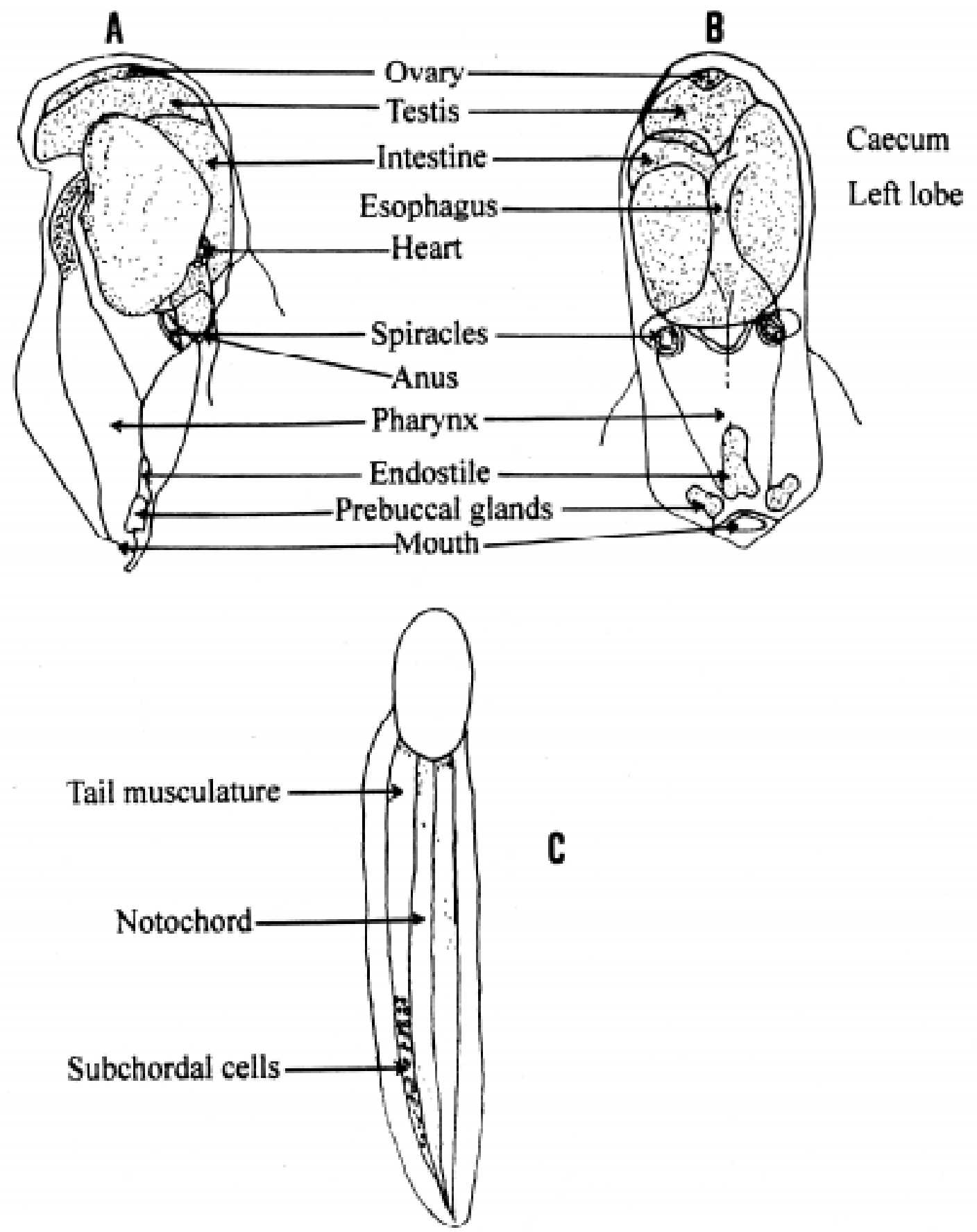

Fig. 2: Family Oikopleuridae. Trunk: (A) lateral view, (B) frontal view, (C) general view (Esnal 1981). Familia Oikopleuridae. Tronco: (A) vista lateral, (B) vista frontal, (C) vista general (Esnal 1981). 
aesophagus is generally inserted in the left lobe of the stomach.

Species: Oikopleura longicauda (Vogt 1854), O. cophocerca (Gegenbaur 1885), O. dioica Fol 1872, O. rufescens Fol 1872, O. fusiformis Fol 1872, O. albicans (Leuckart 1853) and O. gracilis Lohmann 1896.

Genus Megalocercus. Trunk moderately laterally compressed. Buccal cells absent. The left lobe of the stomach is very small. The median part of the stomach rests on the median part of the intestine. The spiracle cilia are restricted anteriorly to a small section. Esophagus short, curved and inserted into the stomach. Stomach undivided. Tail without subchordal or amphichordal glands.

Species: Megalocercus abyssorum Chun, 1887.

Family Fritillariidae. Body dorsoventrally compressed. The endostyle is curved upwards. Branchial openings with a band of cilia, which connect the pharyngeal cavity with the exterior without a tubular conduit. The spiracles are distinctly placed on the anterior part of the pharyngeal cavity. The stomach wall presents few large cells. The fibroblasts are not visible in the dorsal part of the oikoplastic layer.
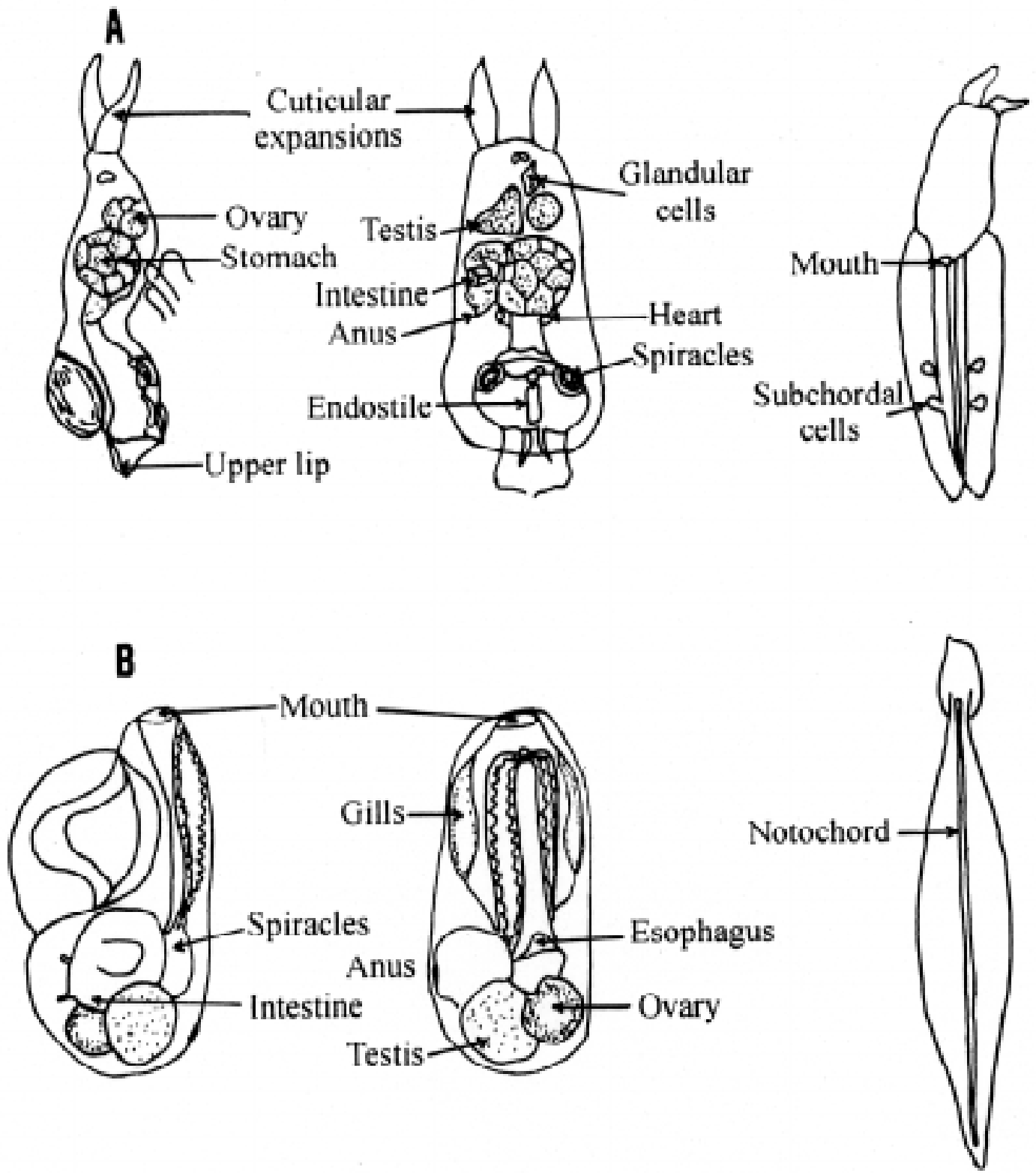

Fig. 3: Family (A) Fritillariidae, (B) Kowalevskiidae. Trunk: (1) lateral view, (2) frontal view, (3) general view (Esnal 1981).

Familia (A) Fritillariidae, (B) Kowalevskiidae. Tronco: (1) vista lateral, (2) vista frontal, (3) vista general (Esnal 1981). 
Subfamily Fritillariinae. Mouth often composed of lobe-like lips. The anterior part of the body and oikoplastic cavity is wide. The tail narrows on its proximal part.

Genus Fritillaria. The gonads are placed behind the intestine. The ciliated layer of the spiracles shows different forms. The dorsal oikoplastic epithelium covers the anterior and median areas of the pharyngeal cavity, while the posterior margin is curved upwards.

Species: Fritillaria pellucida typica Bush 1851, F. pellucida omani Fenaux 1967, F . haplostoma Fol 1874, F. tenella Lohmann 1896, F. formica digitata Lohmann \& Bückmann 1926, $F$. venusta Lohmann 1896, F. fraudax Lohmann 1896.

Analysis of the 221 plankton samples enabled the identification of 15 species, distributed among the genus Oikopleura (seven species), Megalocercus (one specie) and Fritillaria (seven species), all of which are first recorded in waters of the Chilean coast (See Appendix for species identification key). The Oikopleura species were larger in size and found in a better state of preservation than the species of Fritillaria.

Appendicularian abundance fluctuated between 2 and 8,211 ind $100 \mathrm{~m}^{-3}$, with a mean of 81 ind 100 $\mathrm{m}^{-3}$ per station. The greatest concentrations of organisms were found off Antofagasta. The most abundant species were Oikopleura longicauda (56.1 $\%)$, O. gracilis (10.4\%), Fritillaria pellucida typica $(6.7 \%) ; O$. albicans $(5.0 \%) ; F$. pellucida omani $(4.7 \%) ; O$. cophocerca $(4.4 \%)$ and $F$. venusta $(4.1$ $\%)$, whereas the eight remaining species constituted $8.6 \%$ of the total appendicularians collected. O. longicauda was found in all sampling stations. The other species were scarce and distributed beyond $10 \mathrm{~nm}$ off the coast and the species richness increased in this area.

\section{Oikopleura longicauda (Vogt 1854) (Fig. 4)}

References: Tokioka \& Suárez-Caabro (1956) p. 81; Fenaux (1968) pp. 539-542; Esnal (1972) p. 266; Flores-Coto (1974) p. 51; Esnal (1981) p. 826; Fenaux (1993) pp. 76-79; Castellanos \& Gasca (1998) p. 24.

Diagnosis: this species is characterized by the presence of vellum strongly developed and extending dorsally over the trunk, which is often destroyed. Mouth situated forward with a long inferior lip without buccal glands. The left lobe of the stomach has a small finger-shaped caecum directed backwards and upwards. The esophagus penetrates in the left stomach lobe towards the medium dorsal margin. The intestine is short, while the rectum and anus are slightly extended towards the anterior part of stomach. The ovary is placed above the testis. The tail muscles are narrow and the subchordal cells are absent.

Distribution: given its eurythermal and euryhaline features, it was the most common and frequent species in oceanic and coastal waters, showing a wide distribution in the northern zone. Several authors consider this species with the widest geographic distribution among appendicularians (Tokioka \& Suárez-Caabro 1956), even reaching the Polar Front $\left(60^{\circ} \mathrm{S}\right)$ in all oceans.

Records: north Atlantic Ocean (Acuña 1994), south Atlantic (Fenaux 1967,1969a, Esnal 1972, 1979, 1981, 1999, Esnal \& Castro 1977), north Pacific (Tokioka 1955), south Pacific (Fenaux 1968), Indian Ocean (Fenaux 1969b, 1972a), Caribbean Sea (Tokioka \& Suárez-Caabro 1956, Flores-Coto 1965, Castellanos \& Gasca 1998), Mediterranean Sea (Fenaux 1970, Jansá 1985, Raduan et al. 1989) and Red Sea (Fenaux \& Godeaux 1970).

Oikopleura cophocerca (Gegenbaur 1885) (Fig. 4)

References: Tokioka \& Suárez-Caabro (1956) p. 86; Fenaux (1968) pp. 538-544; Flores-Coto (1974) p. 53; Esnal (1981) p. 826; Fenaux (1993) p. 80; Castellanos \& Gasca (1998) pp. 24-28.

Diagnosis: the trunk is elongated and dorsal contour is slightly arched. Mouth with a developed lower lip, prebuccal glands rounded and well developed. Left stomach lobe generally elongated, with a pocket shaped caecum towards its rear end. Esophagus inserts into the dorsal margin of the left stomach lobule. Endostyle small and sited almost at the same distance between the mouth and the anus. Rectum horizontally oriented and the anus is placed near the oral wall of the stomach. An ovary inserted over the testis constitutes the genital apparatus. Tail with 5 to 8 subchordal cells, generally disposed in two groups. The tail musculature is narrow.

Distribution: the larger densities were observed in oceanic waters south of the area of study. It is common in warm and oceanic waters, but generally scarce (Esnal \& Castro 1977); although Gegenbaur (1885) recorded it as one of the most abundant species in winter, in the Bay of Messina. It seems to be scarce in surface waters and most frequent in the cold months (Flores-Coto 1965).

Records: south Atlantic Ocean (Fenaux 1967, 1969a, Bhavanarayana \& Ganapati 1972, Esnal 1972, 1979, 1981, 1999, Esnal \& Castro 1977), north Pacific (Tokioka 1955), south Pacific (Fenaux 1968), Indian Ocean (Fenaux 1969b, 1972a), Caribbean Sea (Flores-Coto 1965, 
Castellanos \& Gasca 1998), Mediterranean Sea (Fenaux 1970, Jansá 1985) and Adriatic Sea (Fenaux 1972b).

Oikopleura dioica Fol 1872 (Fig. 5)

References: Tokioka \& Suárez-Caabro (1956) p. 85; Fenaux (1968) pp. 538-543; Esnal (1972) p. 264; Flores-Coto (1974) p. 54; Fenaux (1976) p.
95; Esnal (1981) p. 826; Fenaux (1993) p. 80; Castellanos \& Gasca (1998) p. 24.

Diagnosis: the trunk is small and globular. Mouth with a prominent lower lip. The endostyle extends from spiracles to near the anus. Prebuccal glands are spherical and small, without a pocket in the left caecum of the stomach. The esophagus penetrates into the stomach by the dorsal margin of the left stomach lobule. The rear wall of the left lobule of the stomach is almost vertical. Rectum

\section{A}

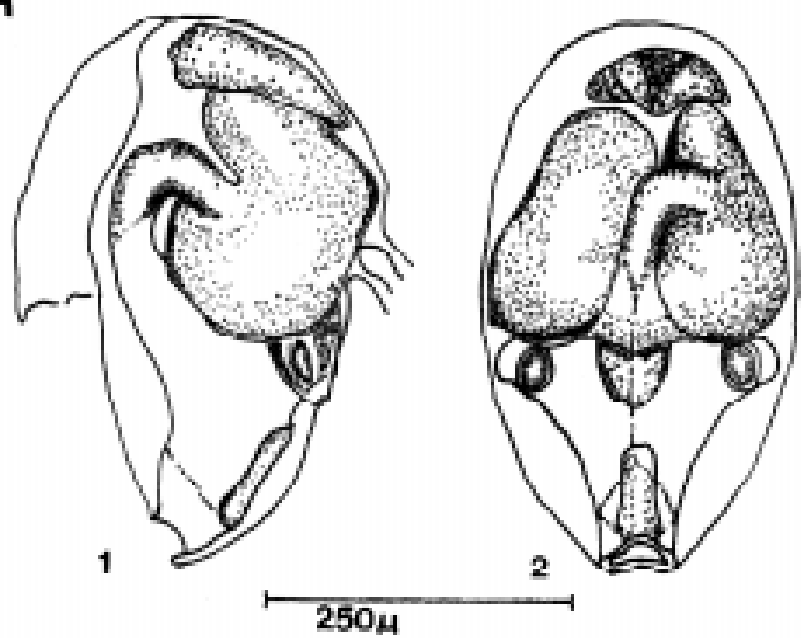

B

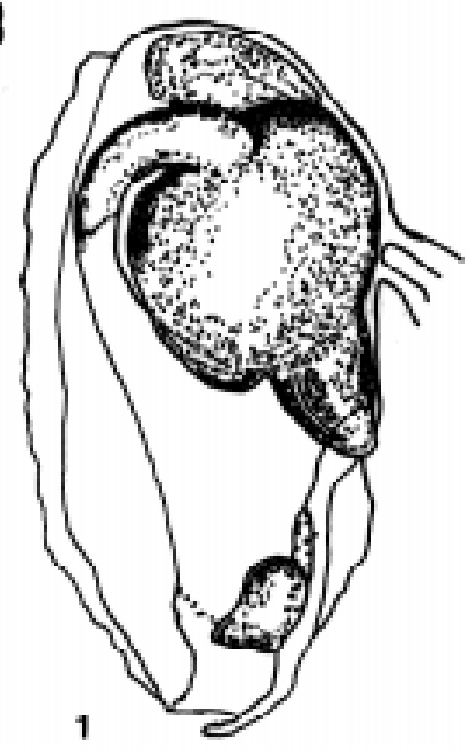

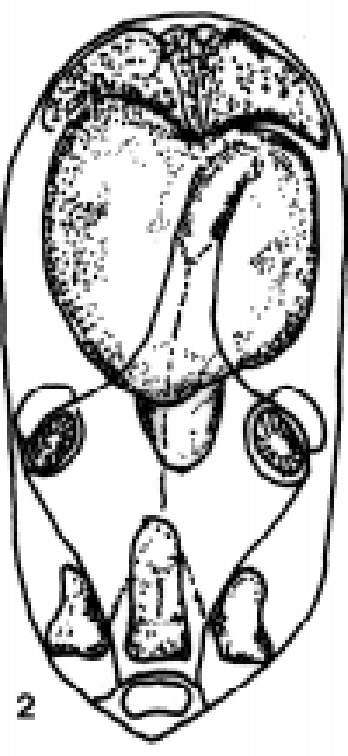
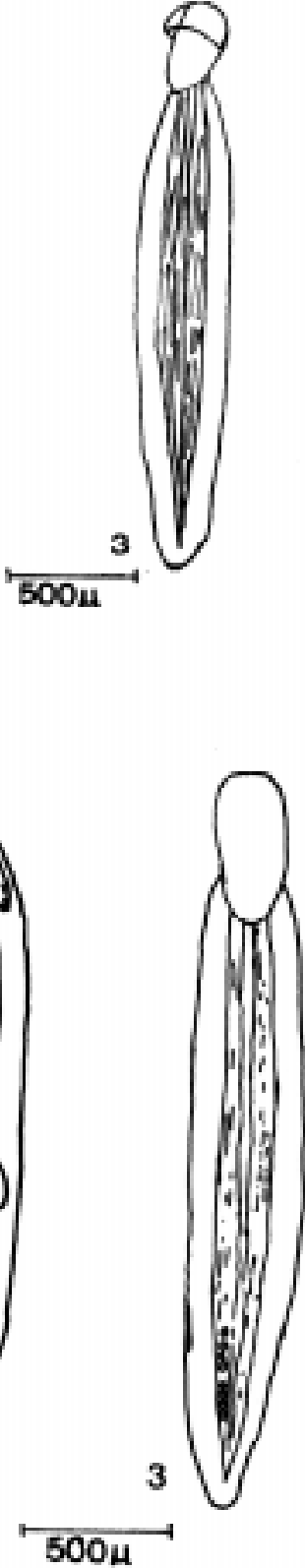

Fig. 4: (A) Oikopleura longicauda; (B) Oikopleura cophocerca. Trunk: (1) lateral view, (2) frontal view, (3) general view (Fenaux 1968).

(A) Oikopleura longicauda, (B) Oikopleura cophocerca. Tronco: (1) vista lateral, (2) vista frontal, (3) vista general (Fenaux 1968). 
is horizontally oblique and the anus is sited near the frontal wall of the stomach. Contrary to the rest of the appendicularians, this species shows separate sexes. Tail with narrow musculature, with two subchordal spindle cells arranged in one row.

Distribution: Oikopleura dioica belongs to neritic environments, frequently is abundant in coastal waters, and very rare in oceanic waters (Fenaux 1967, Esnal 1972). As pointed out by Tokioka \& Suárez-Caabro (1956), Esnal (1972), and Esnal \& Castro (1977), this species showed preferentially a coastal distribution, in some oceanic stations.

Records: north Atlantic Ocean (Acuña 1994), south Atlantic (Fenaux 1967, 1969a, Esnal 1972, 1979, 1981, 1999, Esnal \& Castro 1977, Capitanio et al. 1997), north Pacific (Tokioka 1955), south Pacific (Fenaux 1968), Indian Ocean (Fenaux 1969b), Caribbean Sea (Flores-Coto 1965; Castellanos \& Gasca 1998), Mediterranean Sea (Fenaux 1970, Jansá 1985, Raduan et al. 1989) and Adriatic Sea (Fenaux 1972b).

\section{Oikopleura rufescens Fol 1872 (Fig. 5).}

References: Tokioka \& Suárez-Caabro (1956) p. 86; Fenaux (1968) pp. 540-543; Flores-Coto (1974) p. 53; Esnal (1981) p. 826; Fenaux (1993), p. 80; Castellanos \& Gasca (1998) pp. 24-28.

Diagnosis: trunk compact. Prebuccal glands spherical, large and similar in size. Endostyle is placed almost at equal distance between the mouth and the anus. The rectum is nearly vertical, while the anus is placed under the anterior wall of the stomach. The dorsal outline of the trunk is bent between the digestive region and the genital cavity. The left stomach lobe is eliptically shaped, without a stomach caecum. Gonads dorsal, well developed and tapering towards the rear-end in mature individuals. The ovary is inserted over the testis. The musculature of the tail is dense and wide with only one spindle-shaped subchordal cell arranged in a single row.

Distribution: the largest abundance was recorded in the most distant stations from the coast, confirming their oceanic warm-water character. As in O. longicauda, it is eurythermal, euryhaline and cosmopolitan (Esnal 1981).

Records: north Atlantic Ocean (Acuña 1994), south Atlantic (Fenaux 1967, 1969a, Bhavanarayana \& Ganapati 1972, Esnal 1972, 1979, 1981, 1999, Esnal \& Castro 1977), north Pacific (Tokioka 1955), south Pacific (Fenaux 1968), Indian Ocean (Fenaux 1969b), Caribbean Sea (Castellanos \& Gasca 1998), Mediterranean Sea (Jansá 1985) and Red Sea (Fenaux \& Godeaux 1970).
Oikopleura fusiformis Fol 1872 (Fig. 6).

References: Tokioka \& Suárez Caabro (1956) p. 82; Fenaux (1968) pp. 539-546; Esnal (1972) p. 264; Flores-Coto (1974) pp. 45-52; Esnal (1981) p. 826; Fenaux (1993) p. 79; Castellanos \& Gasca (1998) pp. 24-28.

Diagnosis: the trunk is elongated. Prebuccal glands absent. Mouth opens upward and the aesophagus opens dorsally in the left caecum of stomach. Stomach caecum large and well developed with rear outline curved backwards. Endostyle is placed nearer to the anus than the mouth. Rectum extending towards the anterior wall of the stomach. The gonads are placed below the caecum. During sexual maturity, the gonads increase their size and give the trunk a characteristic elongated curve, and they end up covering the stomach. The ovary is inserted between a large testis. The tail does not show subchordal cells, and the musculature is narrow.

Distribution: mainly in oceanic stations. In the Atlantic Ocean and the Gulf of Benguela this species is distributed mainly in oceanic waters (Fenaux 1969a), although it has also been recorded in waters adjacent to the coast (Esnal 1972).

Records: north Atlantic Ocean (Acuña 1994), south Atlantic (Fenaux 1967, 1969a, Esnal 1979, 1981, 1999, Esnal \& Castro 1977), north Pacific (Tokioka 1955), south Pacific (Fenaux 1968), Indian ocean (Fenaux 1969b), Caribbean Sea (Flores-Coto 1965), Mediterranean Sea (Fenaux 1970, Jansá 1985, Raduan et al. 1989), Red Sea (Fenaux \& Godeaux 1970) and Adriatic Sea (Fenaux 1972b).

\section{Oikopleura albicans (Leuckart 1853) (Fig. 6).}

References: Fenaux (1968) pp. 538-546; Esnal (1972) p. 264; Flores-Coto (1974) p. 52; Fenaux (1993) p. 79.

Diagnosis: the trunk is elongate. The prebuccal glands are voluminous, but different in size. Left stomach lobe with a small caecum directed backwards. In mature stage, the aspect of the trunk is characteristic because of the large development of the gonads that cover the digestive apparatus. Tail with numerous subchordal cells arranged in two rows, musculature moderately narrow.

Distribution: very abundant and distributed mainly in oceanic waters. Esnal \& Castro (1977) stated its preference for waters most distant to the coast and of higher temperature. Bhavanarayana \& Ganapati (1972) indicated that is a common species during the winter season, in the Current of Benguela. 
Records: south Atlantic Ocean (Fenaux 1969a, Bhavanarayana \& Ganapati 1972, Esnal 1972, 1979, 1981, 1999, Esnal \& Castro 1977), north Pacific (Tokioka 1955), south Pacific (Fenaux 1968), Caribbean Sea (Flores-Coto 1965) and Mediterranean Sea (Jansá 1985).
Oikopleura gracilis Lohmann 1896 (Fig. 7).

References: Tokioka \& Suárez-Caabro (1956) p. 81; Tokioka (1955) p. 96; Flores-Coto (1974) pp. 45-51; Esnal (1981) p. 826; Fenaux (1993) p. 78; Castellanos \& Gasca (1998) pp. 24-28.
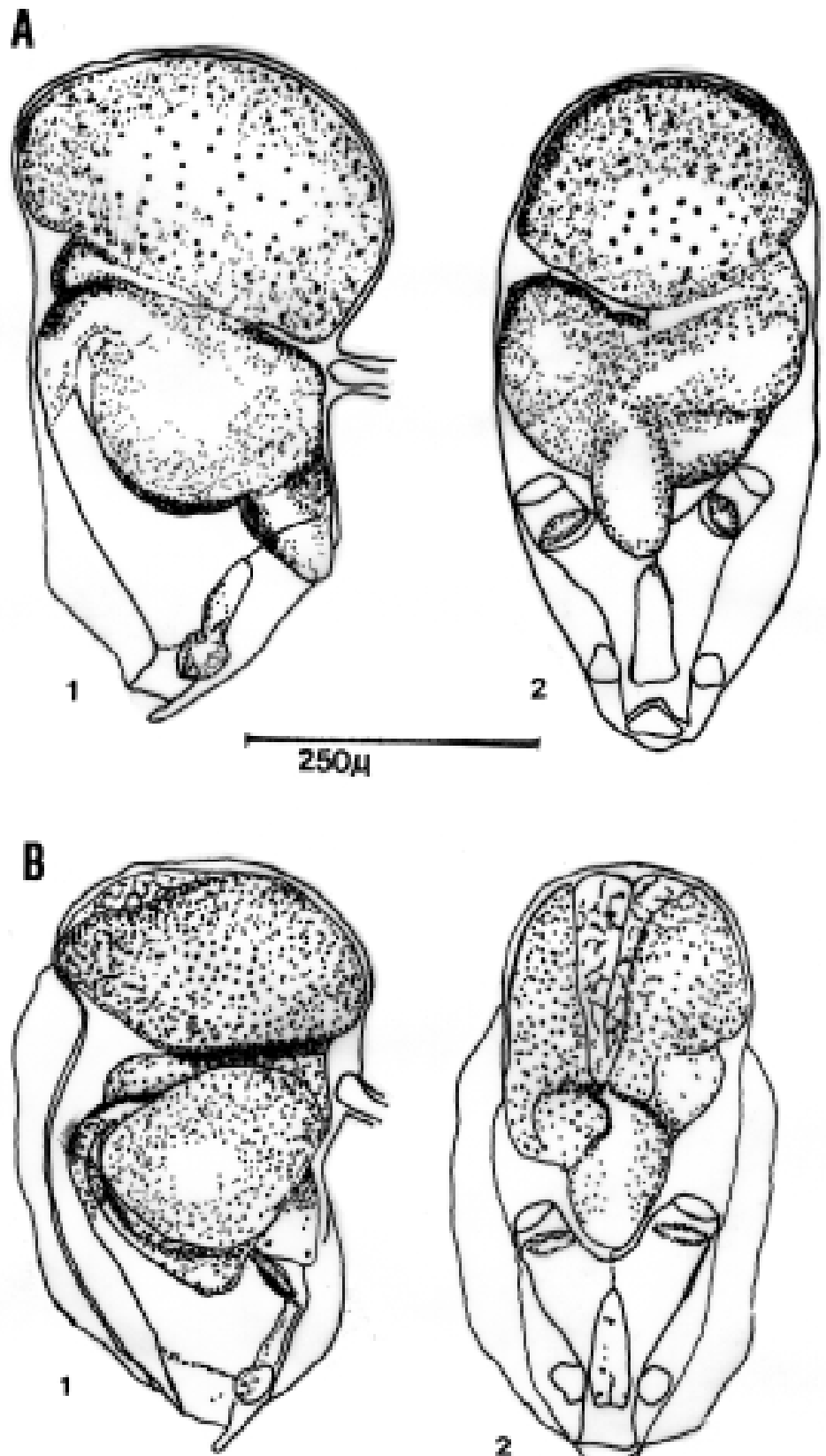

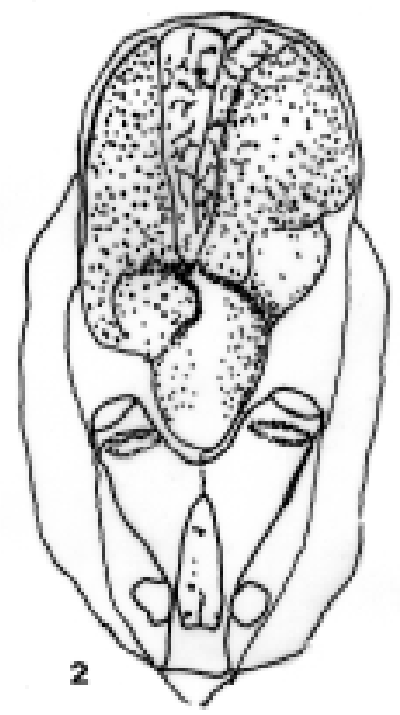

$500_{4}$
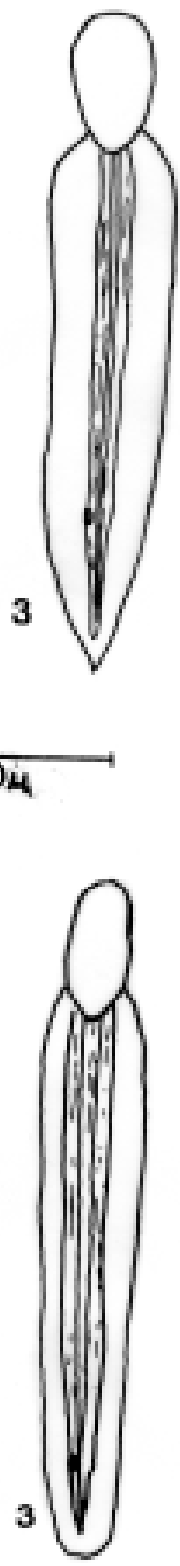

$500 \mu$

14

Fig. 5: (A) Oikopleura dioica, (B) Oikopleura rufescens. Trunk: (1) lateral view, (2) frontal view, (3) general view (Fenaux 1968).

(A) Oikopleura dioica, (B) Oikopleura rufescens. Tronco: (1) vista lateral, (2) vista frontal, (3) vista general (Fenaux 1968). 
Diagnosis: the mouth oriented forwardly. Prebuccal glands absent. The endostyle is placed nearer to the anus than to the mouth. The left stomach lobule is rounded and without a caecum. The aesophagus ends in the dorsal margin of the left lobule of the stomach. The rectum and the anus are placed near the anterior part of the stomach. In mature individuals, the gonads extend dorsally towards the rear, shaping the body char- acteristically. The tail is rather long (up to five times longer than the trunk). Subchordal cells are absent.

Distribution: preferentially in coastal stations. However, Esnal \& Castro (1977) found it only in oceanic stations, therefore it is recognized as an oceanic species of the southwest Atlantic waters.

Records: south Atlantic Ocean (Fenaux 1967, 1969a, Esnal 1979, 1981, 1999, Esnal \& Castro
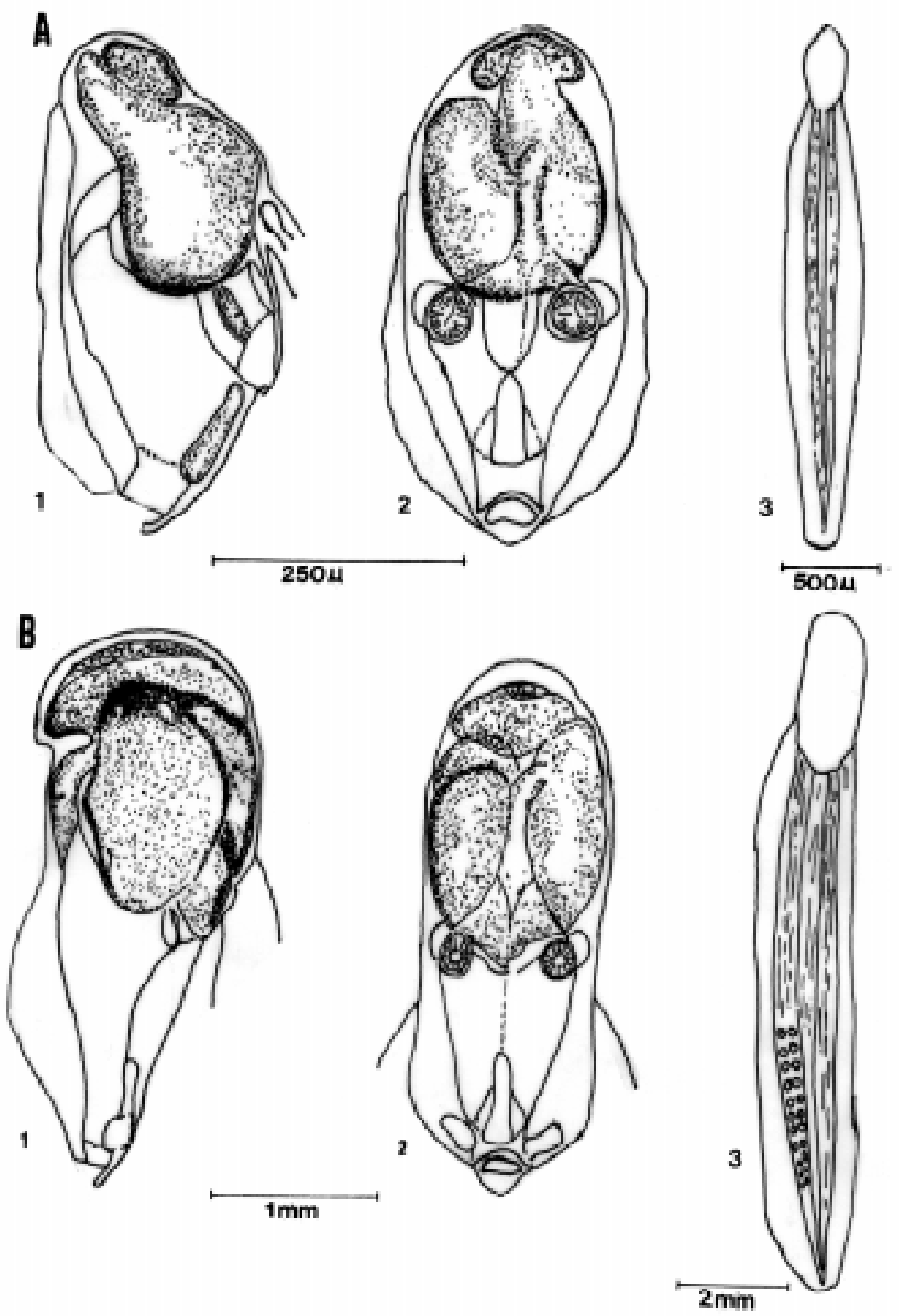

Fig. 6: (A) Oikopleura fusiformis, (B) Oikopleura albicans. Trunk: (1) lateral view; (2) frontal view; (3) general view (Fenaux 1968).

(A) Oikopleura fusiformis, (B) Oikopleura albicans. Tronco: (1) vista lateral, (2) vista frontal, (3) vista general (Fenaux 1968). 
1977), north Pacific (Tokioka 1955), Caribbean Sea (Castellanos \& Gasca 1998), Red Sea (Fenaux \& Godeaux 1970) and Adriatic Sea (Fenaux 1972b).

Fritillaria pellucida typica Bush 1851 (Fig. 8).

References: Tokioka \& Suárez-Caabro (1956) p. 81; Fenaux (1966) p. 148; Esnal (1973) p. 271; Flores-Coto (1974) p. 54; Fenaux (1993) pp. 4485; Castellanos \& Gasca (1998) p. 25.

Diagnosis: trunk is almost rectangular, dorsoventrally compressed with two long conical cuticular expansions well separated in the posterior region. Mouth with a prominent lower lip. Endostyle elongated and appears slightly curved. The spiracles are spherical. There is a set of five to six glandular cells between the almost extreme of the endostyle and the left spiracle. The digestive nucleus is small and directed towards the mid region of the trunk. The ovary is spherical and placed to the left side of the body. Testis asymmetric, $r$-shaped and extended to the right side of the body. Tail with wide musculature and two pairs of amphichordal cells with visible secretor channels, which are placed on each side of the notochord.

Distribution: mainly in the oceanic area. Esnal (1981) indicated that this variety is very frequent in all oceans and its preference for oceanic waters has been cited by several authors (Fenaux 1969b, Esnal 1972, Esnal \& Castro, 1977).

Records: north Atlantic Ocean (Acuña 1994), south Atlantic (Fenaux 1967, 1969a, Esnal 1972, 1981, 1999), north Pacific (Tokioka 1955), Indian Ocean (Fenaux 1969b, 1972a), Caribbean Sea (Castellanos \& Gasca 1998), Mediterranean Sea (Jansá 1985, Raduan et al. 1989), Red Sea (Fenaux \& Godeaux 1970), Adriatic Sea (Fenaux 1972b) and Arabian Sea (Fenaux 1966).
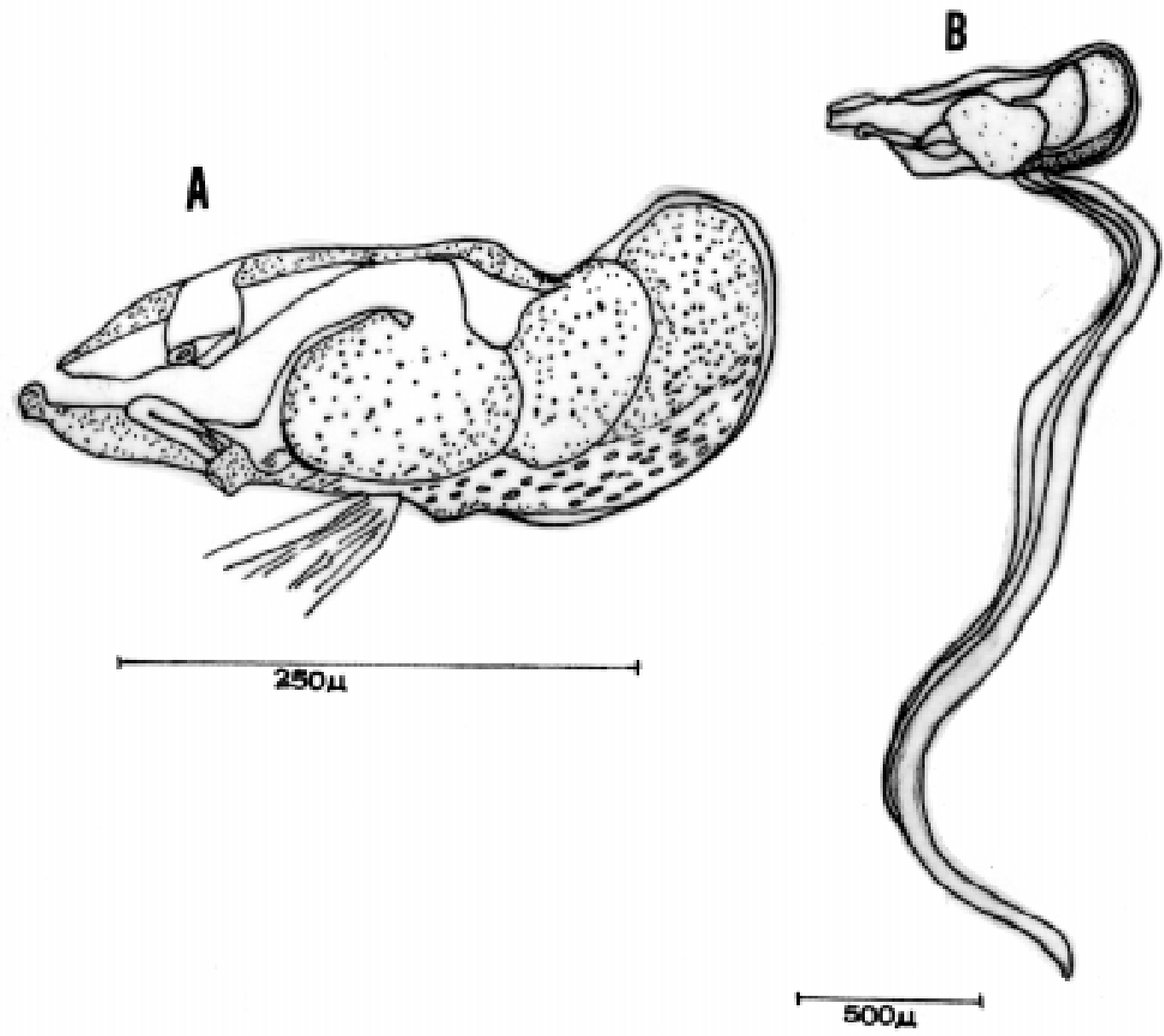

Fig. 7: Oikopleura gracilis. Trunk: (A) lateral view; (B) general view (Flores-Coto 1974, Tokioka 1955).

Oikopleura gracilis. Tronco: (A) vista lateral, (B) vista general (Flores-Coto 1974, Tokioka 1955). 
Fritillaria pellucida omani Fenaux 1967 (Fig. 8).

References: Fenaux (1966) p. 148; Esnal (1973) p. 271; Fenaux (1993) pp. 44-85; Castellanos \& Gasca (1998) p. 25.

Diagnosis: trunk oval, dorsoventrally compressed with two short spherical cuticular expansions well separated posteriorly. Mouth with a prominent lower lip. The endostyle is elongated and appears slightly curved. The spiracles are spherical. The digestive nucleus is small and directed towards the mid region of the trunk. Ovary spherical and placed to the left side of the body. Testis asymmetric, Y-shaped and extended towards the right side of the body. Tail with wide musculature and two pairs of amphichordal cells with visible secretor channels, placed on both sides of the notochord.

Distribution: distribution pattern quite similar to that of $F$. pellucida typica, showing a greater

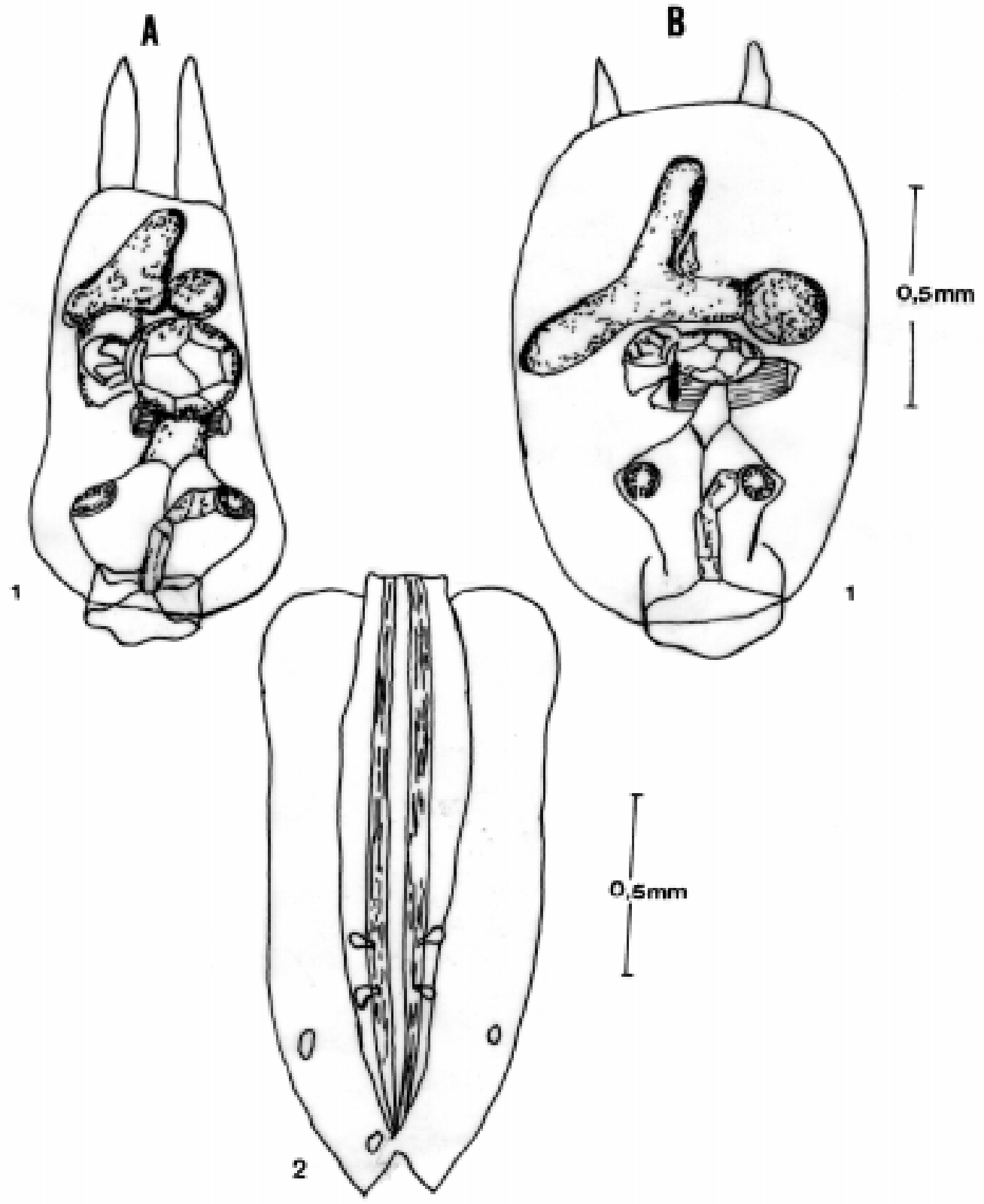

Fig. 8: (A) Fritillaria pellucida typica, (B) Fritillaria pellucida omani. (1) frontal view; (2) general view of tail (Fenaux 1993).

(A) Fritillaria pellucida typica, (B) Fritillaria pellucida omani. (1) vista frontal, (2) vista general de la cola (Fenaux 1993). 
preference for oceanic waters. Fenaux (1969a) pointed out the similarity of the distribution pattern of both varieties, which are common to all oceans (Esnal 1981). Several authors have recorded its oceanic presence (Fenaux 1969b, Esnal 1972, Esnal \& Castro 1977).

Records: north Atlantic Ocean (Acuña 1994), south Atlantic (Fenaux 1967,1969a, Esnal 1972, 1981, 1999), Indian Ocean (Fenaux 1969b, 1972a), Caribbean Sea (Castellanos \& Gasca 1998), Mediterranean Sea (Jansá 1985), Red Sea (Fenaux \& Godeaux 1970), Adriatic Sea (Fenaux 1972b) and Arabian Sea (Fenaux 1966).
Fritillaria haplostoma Fol 1874 (Fig. 9).

References: Tokioka \& Suárez Caabro (1956) p. 90; Tokioka (1955) p. 100; Flores-Coto (1974), p. 56; Esnal (1981) p. 825; Fenaux (1993) p. 83; Castellanos \& Gasca (1998) p. 24.

Diagnosis: body elongated, bent and dorsoventrally compressed. The mouth has a single ciliated ring and a large upper lip. The digestive tract is longitudinal and the spiracles are circular. The stomach is spherical, with some standing out cells of the wall. The intestine is placed behind the stomach, whereas the endostyle is short and
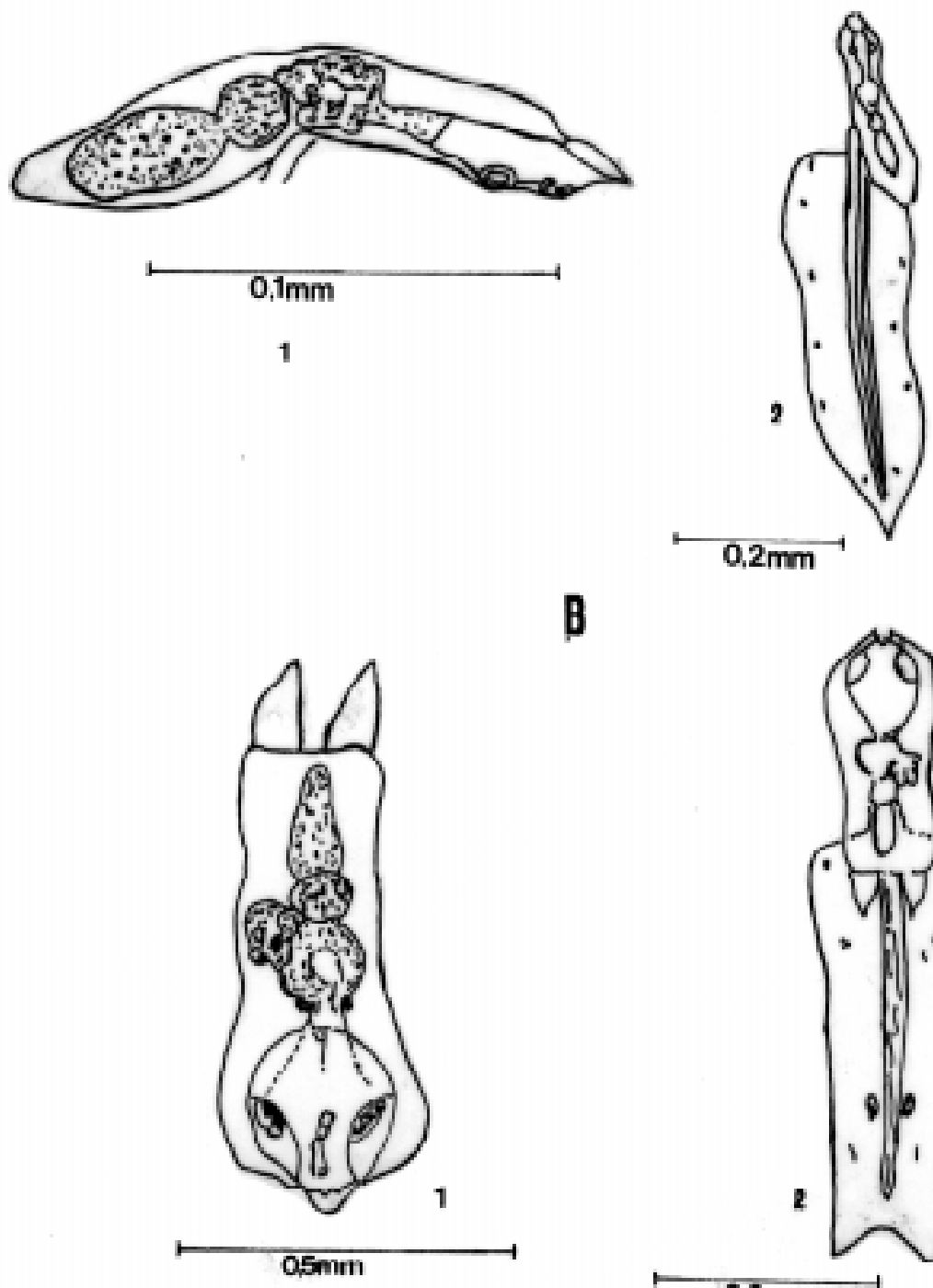

B

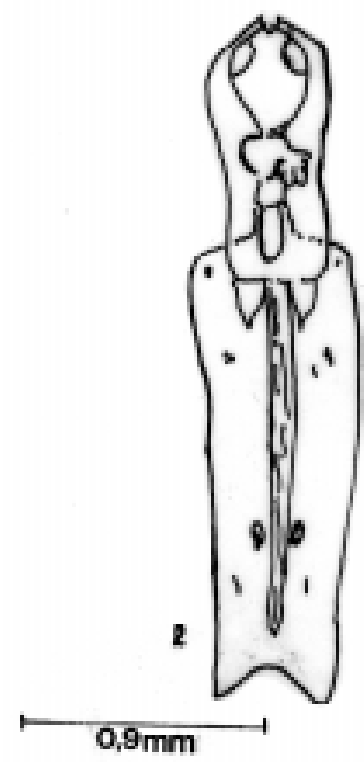

Fig. 9: (A) Fritillaria haplostoma, (B) Fritillaria tenella. Trunk: (1) lateral view; general view (Tokioka 1955, Tokioka \& Suárez-Caabro 1956, Esnal 1981).

(A) Fritillaria haplostoma, (B) Fritillaria tenella. Tronco: (1) vista lateral, vista general (Tokioka 1955, Tokioka \& Suárez-Caabro 1956, Esnal 1981). 
curved. The ovary is spherical, followed by an elongated cylindrical testis. Tail is wide and acuminate toward its distal extreme, musculature is narrow and does not reach until the end of the notochord. Tail with numerous small glandular cells.

Distribution: as observed by Esnal \& Castro (1977), it was found exclusively in oceanic waters. However, in other regions is preferentially distributed in neritic waters and oceanic warm zones (Tokioka \& Suárez-Caabro 1956, Esnal 1972, 1981).

Records: south Atlantic Ocean (Fenaux 1967,1969a, Bhavanarayana \& Ganapati 1972, Esnal 1972, 1979, 1981, 1999, Esnal \& Castro 1977), north Pacific (Tokioka 1955), Indian Ocean (Fenaux 1969b, Caribbean Sea (Castellanos \& Gasca 1998), Mediterranean Sea (Jansá 1985) and Adriatic Sea (Fenaux 1972b).

\section{Fritillaria tenella Lohmann 1896 (Fig. 9).}

References: Esnal (1981) p. 825; Fenaux (1993) p. 85 .

Diagnosis: body elongated, almost rectangular and dorsoventrally compressed, with two cuticular expansions in the rear end of the body. The gonads are symmetric, with an spherical anterior ovary followed by an elongated testis. The tail has narrow musculature and two amphichordal multicellular glands on each side the notochord, opened in their distal region.

Distribution: found mainly in oceanic waters, accordingly with its distribution in waters of the southwest Atlantic ocean (Esnal \& Castro 1977, Esnal 1981).

Records: north Atlantic Ocean (Fenaux 1967), south Atlantic (Fenaux 1969a, Esnal 1981, 1999), north Pacific (Tokioka 1955) and Mediterranean Sea (Fenaux 1970).

Fritillaria formica digitata Lohmann \& Bückmann 1926 (Fig. 10).

References: Tokioka (1955) p. 80; Flores-Coto (1974) p. 55; Esnal (1981) p. 825; Fenaux (1993) p. 83; Castellanos \& Gasca (1998) p. 25.

Diagnosis: the body is elongated and bent upwards in the digestive nucleus region. The ciliated arches of the spiracles are not in contact with the mid ventral line. The posterior margin of the oikoplastic layer is extended towards the stomach. Mouth with median lobe of the upper lip small, short and provided anteriorly with two finger-shaped bulges. Testis more or less conical with circular angles and two posterior ornament in mature individuals.

Distribution: found mainly in oceanic waters. Common in the oceanic area of warm seas. It is one of the most common species in the southwest Atlantic (Esnal \& Castro 1977, Esnal 1981, 1999).

Records: south Atlantic Ocean (Fenaux 1969a, Bhavanarayana \& Ganapati 1972, Esnal 1981,1999), Indian Ocean (Fenaux 1969b, 1972a), Caribbean Sea (Castellanos \& Gasca 1998) and Mediterranean Sea (Raduan et al. 1989).

Fritillaria venusta Lohmann 1896 (Fig. 10).

References: Esnal (1981) p. 825; Fenaux (1993) p. 85 .

Diagnosis: body expanded, dorsoventrally compressed, almost rectangular and laterally narrow at the level of the digestive nucleus. Trunk with cuticular extensions on its posterior part. In young individuals the gonads are globular, whereas in mature individuals, the testis is trapezoidal and laterally surrounded by a well-developed rosaryshaped (moniliform) ovary. One single amphichordal cell on both sides of the tail, and narrow musculature.

Distribution: present mainly in the most oceanic stations. It is one of the most abundant species of the southwest Atlantic warm waters (Esnal \& Castro 1977, Esnal 1981). Fenaux (1969a) and Esnal (1981) considered that $F$. venusta is an eurythermal and cosmopolite species, inhabiting neritic, as well as oceanic waters.

Records: south Atlantic Ocean (Fenaux 1967, 1969a, Esnal 1981, 1999) and north Pacific (Tokioka 1955).

\section{Fritillaria fraudax Lohmann 1896 (Fig. 11).}

References: Esnal (1981) p. 825; Fenaux (1993) p. 87 .

Diagnosis: the trunk is slightly oval. Mouth with two lateral lobes. The spiracles are oval and elongated. Digestive tract is transverse and the endostyle is curved. Two globular processes are present in the pyloric region. The rectum almost vertical and well developed. The ovary is moniliform, anteriorly curved and surrounds a slightly concave testicle. The tail has narrow musculature, without amphichordal cells.

Distribution: its presence in nearshore stations suggests a strong preference for neritic waters, but it might as well be in oceanic waters. Esnal (1981, 1999) classified $F$. fraudax as a thermophilic and cosmopolite specie, scarce over the Argentinean shelve; but, it has been found abun- 
dant and frequently collected between 34 and $41^{\circ}$ S (Esnal 1981).

Records: south Atlantic Ocean (Fenaux 1969a, Bhavanarayana \& Ganapati 1972, Esnal 1981, 1999) and north Pacific (Tokioka 1955).

Megalocercus abyssorum Chun 1887 (Fig. 11).

References: Tokioka (1958) p. 2; Fenaux (1964) p. 982; Esnal \& Castro (1977) p. 244; Esnal (1981) p. 825; Fenaux (1993) p. 76-81.

Diagnosis: trunk elongated. The stomach is well developed, tubular and covering most of the in- testine. Spiracles with cilia placed only over the anterior arch. The posterior margins of the endostyle are not close to the anus. Tail without subchordal cells, musculature narrow.

Distribution: the majority of the specimens collected was distributed in the oceanic stations and was more frequent than in other geographic areas (Esnal \& Castro 1977, Fenaux 1981). Recorded in the Atlantic Ocean and the Mediterranean Sea, classified as a thermophilic species (Fenaux 1981). This genera is comprised by three species, exclusively restricted to tropical waters: Megalocercus atlanticus, distributed in waters of the Atlantic ocean, M. huxleyi confined to the Indo-Pacific,
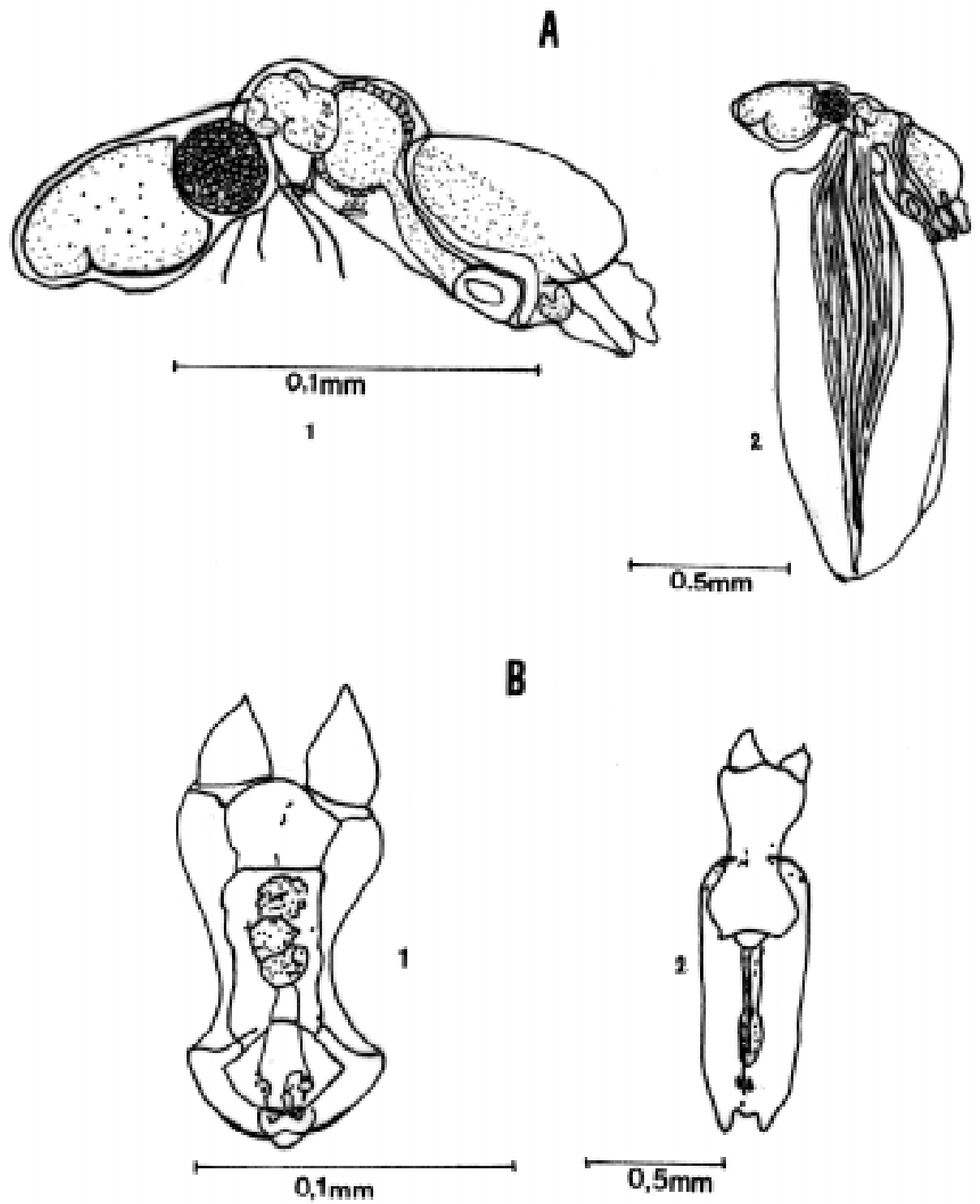

Fig. 10: (A) Fritillaria formica digitata, (B) Fritillaria venusta. Trunk: (1) lateral and frontal view; (2) general view (Esnal 1981).

(A) Fritillaria formica digitata, (B) Fritillaria venusta. Tronco: (1) vista lateral y frontal, (2) vista general (Esnal 1981). 
and $M$. abyssorum in waters of the Mediterranean Sea (Esnal \& Castro 1977). These authors collected M. abyssorum in only one oceanic station, stating that is a very rare species in waters of the Atlantic Ocean.

Records: south Atlantic Ocean (Esnal 1981, 1999, Esnal \& Castro 1977), north Pacific (Tokioka 1958) and Mediterranean Sea (Fenaux 1964).

\section{DISCUSSION}

The lack of knowledge of the appendicularians of the southeast Pacific waters has led several authors to ignore the contribution of these organisms to the trophic ecology of the marine zooplankton. The main reasons explaining the scarcity of works on this group, has been its reduced size and the spoilage suffered by the specimens during the collection, thus making very difficult its taxonomic analysis (Esnal 1981).

Nevertheless, the appendicularians constitute an important link in the trophic web, because their filtration system is the most adapted and specialized of the planktonic herbivores. Besides, they ingest pico- and nanoplankton, contrary to the copepods and their larval stages of nauplius and copepodits, they are able to consume high percentages of particulate organic carbon (Alldredge 1981).

Preliminary estimates made in waters of the center-south area of Chile show that the appendicularians uses a low percentage of primary production $(<5 \%)$ in the house production, respiration, and secondary production. However, the high volumes of water that they filter suggest

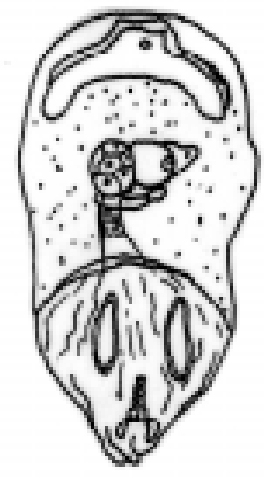

1
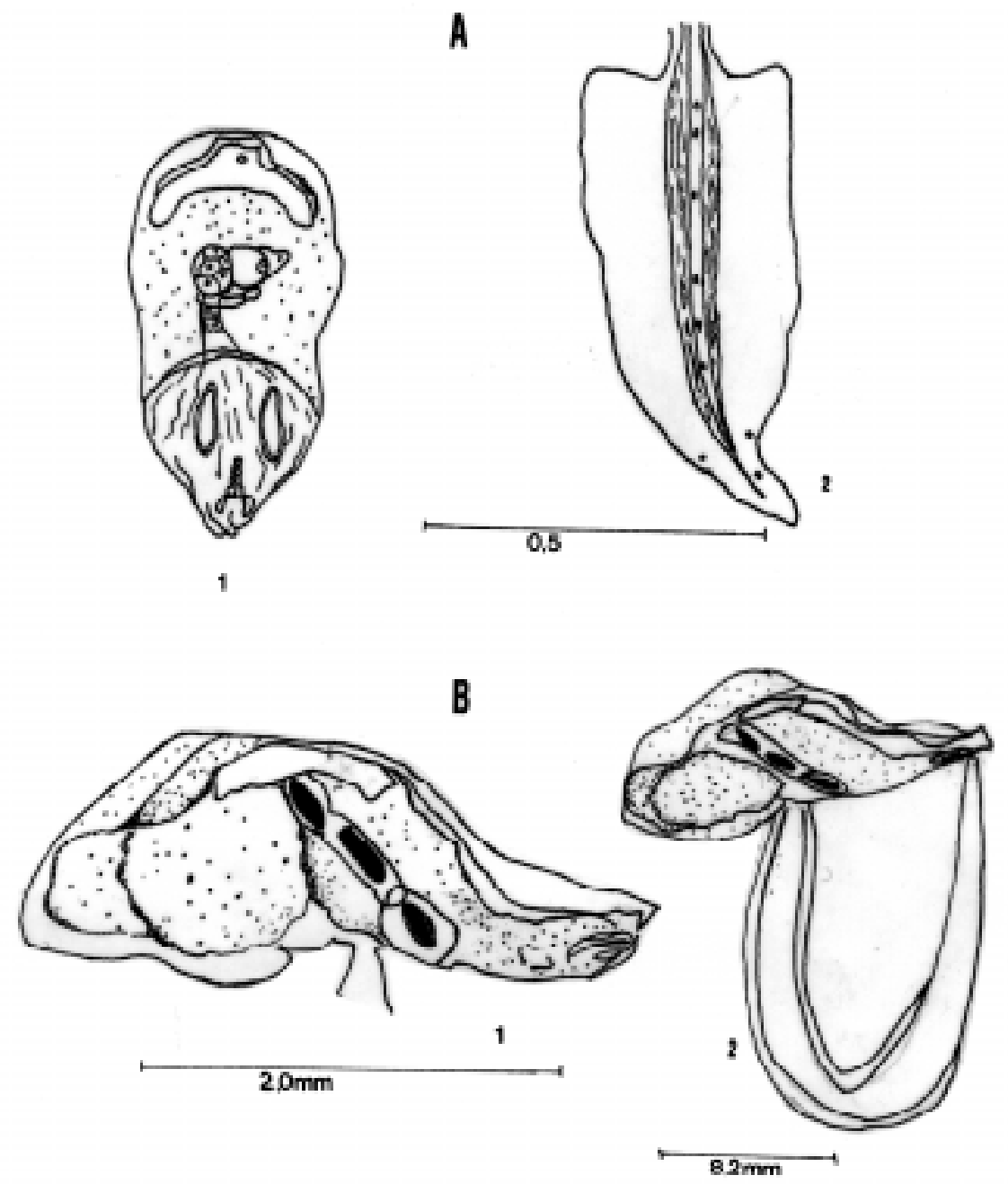

Fig. 11: (A) Fritillaria fraudax. Trunk: (1) frontal view, (2) view of tail. (B) Megalocercus abyssorum. Trunk: (1) lateral view, (2) general view (Esnal 1981, Flores-Coto 1974).

(A) Fritillaria fraudax. Tronco: (1) vista frontal, (2) vista de la cola. (B) Megalocercus abyssorum. Tronco: (1) vista lateral, (2) vista general (Esnal 1981, Flores-Coto 1974). 
an active participation in the pelagical trophic webs (Grunewald et al. 1998).

Appendicularians connect the nanoplankton with a large number of other marine organisms preying upon them, or upon the houses they eject periodically, thus becoming a rich source of available food. Alldredge (1976) analyzed the ecological significance of the abandoned houses, observing that a large quantity of copepods, ostracods and some euphausiid larvae consumed this organic material. Some species are sometimes important in the diet of several fishes, including larvae and adults. Herring and anchovy in the Atlantic Ocean and sardine in the Pacific Ocean, are examples showing that appendicularians can be an alternative source of food for some fish of economic importance (Tokioka \& Suárez-Caabro 1956, Esnal 1981, Capitanio et al. 1997).

The appendicularians are very common in plankton samples and most species are epipelagic and cosmopolitan, with high affinity to warm subtropical waters. Highest diversities have been reported from the warmest waters, but many of the species are eurythermic, extending broadly into temperate and cold waters (Fenaux \& Godeaux 1970, Esnal 1981, 1999, Fenaux 1993). The identified species constitutes the first record for Chilean waters, extending their distribution range in this region of the southeastern Pacific. Most of these species have been recorded previously off the coasts of Argentina and Brazil (Esnal 1972, 1979, 1981, Esnal \& Castro 1977), in Caribbean waters (Tokioka \& Suárez-Caabro 1956, FloresCoto 1965, Castellanos \& Gasca 1998) and in the northwest Pacific (Tokioka 1955, 1958).

Given the specificity of their environmental requirements, some species have been suggested as possible indicators of water masses. Such as $O$. labradoriensis and $O$. vanhoeffeni to differentiate water masses in the north Atlantic (Tokioka \& Suárez-Caabro 1956) and O. dioca to indicate the presence of coastal waters in the southwestern Atlantic Ocean (Esnal 1972).

In the southeastern Pacific Ocean, Fenaux (1968) recorded the presence of Oikopleura longicauda, $O$. dioica, O. albicans, $O$. fusiformis and $O$. rufescens, in Peruvian waters. Now, for the first time, can be added for Chilean waters, $O$. gracilis, O. cophocerca, Megalocercus abyssorum, Fritillaria haplostoma, F. pellucida typica, F. pellucida omani, F. fraudax, $F$. formica digitata, $F$. tenella and $F$. venusta. However, the apparently greater number of species recorded in the northern zone of Chile, does not allow concluding an increment of species richness from Peruvian to Chilean waters, due to the small number of samples analyzed by
Fenaux (1968). Besides, the presence of several species of the family Fritillariidae has been observed, as opposed to what has been recorded in the Peruvian coast, where all species were included in the Oikopleuridae, which is the most common family of the appendicularians in all oceans. Recently, Grunewald et al. (1998) analyzed the space distribution of the apendicularias collected in the centersouth area of Chile, but all the individuals were attributed to the family Oikopleuridae, without identifying the species. The results obtained in winter in northern Chile, show a similar number of species of the families Oikopleuridae (eight species) and Fritillariidae (seven species), although with a marked abundance of individuals belonging to Oikopleuridae $(81.2 \%)$.

By their eurythermic and euryhalines characteristics, O. longicauda is the most abundant (56.1 $\%)$ and frequent in the coastal and oceanic waters in northern Chile. This wide distribution confirms the results obtained in different oceans indicating that this species is the most abundant and widely distributed appendicularia in all oceans (Tokioka \& Suárez-Caabro 1956, Fenaux 1963, Esnal \& Castro 1977, Esnal 1999).

The presence of this set of 15 species recorded for the first time in Chilean waters allows us to extend the range of geographic distribution of these organisms in the Pacific Ocean waters, and to incorporate this set of species to the inventory of plankton biodiversity of Chilean waters.

\section{ACKNOWLEDGEMENTS}

The authors are grateful to Mr. Mauricio Braun from the Instituto de Fomento Pesquero, for the plankton samples obtained by the Project FIP 9503 on Hydroacoustic resource assessment of anchovy, jack mackerel and Spanish sardine from regions I trough IV. To Dr. Graciela Esnal from the University of Buenos Aires for her valuable collaboration.

\section{LITERATURE CITED}

ACUÑA JL (1994) Summer vertical distribution of appendicularians in the central Cantabrian sea (bay of Biscay). Journal of Marine Biological Association of the United Kingdom 74: 585-601.

ALLDREDGE A (1976) Field behavior and adaptative strategies of appendicularians (Chordata: Tunicata). Marine Biology 38: 29-39.

ALLDREDGE A (1981) The impact of appendicularian grazing on natural food concentration in situ. Limnology and Oceanography 26: 247-257. 
BARBER R, R DUGDALE, J MAC-ISAAC \& R SMITH (1971) Variations in phytoplankton growth associated with the source and conditioning of upwelling water. Investigaciones Pesqueras (Chile) 25: 1-35.

BARBER RT \& F CHÁVEZ (1983) Biological consequences of El Niño. Science 222: 1203-1210.

BARHAM E (1979) Giant larvacean houses: observations from deep submersibles. Science 205: 1129-1131.

BHAVANARAYANA P \& P GANAPATHI (1972) Distribution of pelagic tunicates in the western part of the Bay of Bengal. Proceedings of the Indian Academy of Science 72: 1-14.

CAILLIET G \& A EBELING (1990) The vertical distribution and feeding habits of two common midwater fishes (Leuroglossus stilbius and Stenobrachius leucopsaurus) off Santa Barbara. Calcofi Report (United States) 31: 106-123.

CAPITANIO F, M PAJARO \& G ESNAL (1997) Appendicularians (Chordata, Tunicata) in the diet of anchovy (Engraulis anchoita) in the Argentine sea. Scientia Marina 61: 9-15.

CASTELLANOS I \& R GASCA (1998) Lista faunística y clave de identificación de las apendicularias (Urochordata: Larvacea) del Caribe mexicano. Avacient (México) 24: 26-29.

CUSHING D (1969) Upwelling and fish production. FAO Fish Technology Paper 84: 1-40.

ESNAL G (1972) Apendicularias de la desembocadura del Río de la Plata. Physis (Argentina) 31: 259-272.

ESNAL G (1973) Apendicularias de las costas argentinas. Physis (Argentina) 32: 267-273.

ESNAL G (1979) Características generales de la distribución de tunicados pelágicos del Atlántico sudoccidental, con algunas observaciones morfológicas. Physis (Argentina) 38: $91-102$

ESNAL G (1981) Apendicularia. In: Boltovskoy (ed) Atlas del zooplancton del Atlántico sudoccidental y métodos de trabajo con el zooplancton marino: 809-820. Publicación Especial, Instituto Nacional de Investigación y Desarrollo Pesquero, Mar del Plata, Argentina. 936 pp.

ESNAL G (1999) Appendicularia. In: Boltovskoy D (ed) South Atlantic zooplancton: 1375-1399. Backhuys Publication, Leiden, The Netherlands.

ESNAL G \& R CASTRO (1977) Distributional and biometrical study of appendicularians from the west south Atlantic Ocean. Hydrobiologia 56: 241-246.

FENAUX R (1964) Contribution à la connaissance d'un appendiculaire peu commun Megalocercus abyssorum Chun, 1888. Viet et Milieu 15: 979-991.

FENAUX R (1966) Une variété de Fritillaria pellucida (Bush 1851), récoltée dans la mer d'Oman. Cahiers d'ORSTOM, série Océanographie 4: 147-151.

FENAUX R (1967) Les appendiculaires de la campagne de la "Calypso" en Amérique du Sud. Résultats Scientifiques des Campagnes de la "Calypso" 8: 33-46.

FENAUX R (1968) Algunas apendicularias de la costa peruana. Boletín del Instituto del Mar (Perú) 1: 536-552.
FENAUX R (1969a) Les appendiculaires du Golfe du Bengale. International Journal on Life in Oceans and Coastal Waters 2: 252-263.

FENAUX R (1969b) Les appendiculaires de Madagascar (Région de Nosy-Bé) variations saisonnières. Cahiers d'ORSTOM, série Océanographie 7: 29-37.

FENAUX R (1970) Sur les appendiculaires de la Méditerranée orientale. Bulletin du Muséum National d'Histoire Naturelle (France) 42: 1208-1211.

FENAUX R (1972a) Les appendiculaires de la partie centrale de 1'ocean Indien. Journal of Marine Biology Association of India 14: 496-511.

FENAUX R (1972b) Variations saisonnières des appendiculaires de la región nord Adriatique. Marine Biology 16: 310-319.

FENAUX R (1993) The classification of Appendicularia (Tunicata): history and current state. Mémoires de l'Institut Océanographique (Monaco) 17: 1-123.

FENAUX R \& J GODEAUX (1970) Répartition verticale des tuniciers pélagiques au large d'Eilat (Golfe d'Aqaba). Bulletin de la Société Royale des Sciences de Liège (Belgium) 39: 200-209.

FLORES-COTO C (1965) Notas preliminares sobre la identificación de las apendicularias de las aguas veracruzanas. Anales del Instituto de Biología (México) 35: 293-296.

FLORES-COTO C (1974) Contribución al conocimiento de las apendicularias del arrecife "La Blanquilla" Veracruz, México con descripción de una nueva especie. Anales del Centro de Ciencias del Mar y Limnología, Universidad Nacional Autónoma de México 1: 41-60.

GRUNEWALD A, R QUIÑONES \& S NÚÑEZ (1998) Distribución espacial y flujos de materia asociados a apendicularias (Chordata, Tunicata) en la zona centrosur de Chile. Gayana Oceanología (Chile) 6: 11-23.

JANSÁ J (1985) Apendicularias, salpas y plancton en general en la zona W y S de Mallorca. Boletín del Instituto Español de Oceanografía 2: 132-154.

MANN KH \& JR LAZIER (1996) Dynamics of marine ecosystems: biological-physical interactions in the oceans. Blackwell Scientific Publications, Oxford, United Kingdom. 394 pp.

OHTSUKA S \& N KUBO (1991) Larvaceans and their houses as important food some pelagic copepods. Bulletin of Plankton Society of Japan, Special Volume: 535-551.

RADUAN A, C BLANCO, E SOLER \& JG DEL RÍO (1989) Appendicularian dynamics and the influence of runoff on their distribution in the Bay of Cullera Spanish Mediterranean. Scientia Marina 53: 2-3.

TOKIOKA T (1955) General considerations on Japanese appendicularian fauna. Publications of the Seto Marine Biological Laboratory 4: 251-261.

TOKIOKA T (1958) Further notes on some appendicularians from the eastern Pacific. Publications of the Seto Marine Biological Laboratory 7: 1-17.

TOKIOKA T \& J SUÁREZ-CAABRO (1956) Apendicularias de los mares cubanos. Memorias de la Sociedad Cubana de Historia Natural 23: 37-95. 
APPENDIX 1

Key to collected appendicularians

(Fenaux 1968, Esnal 1981, Castellanos \& Gasca 1998)

Clave para las apendicularias recolectadas

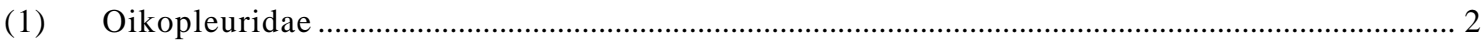

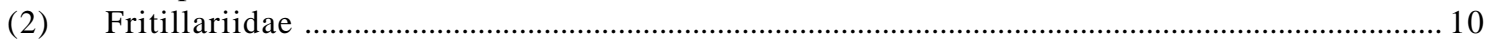

(2a) Stomach with left lobe well developed ...................................................................................... 3

(2b) Stomach with right and left lobes well developed, Genus Oikopleura ..................................... 4

(3) Spiracles with cilia placed only over the anterior arch ........................ Megalocercus abyssorum

(4a) Mouth with prebuccal glands and subchordal cells present ..................................................... 5

(4b) Mouth opens forwardly, prebuccal glands and subchordal cells absent ................................... 8

(5a) Subchordal cells numerous, arranged in two rows ....................................... Oikopleura albicans

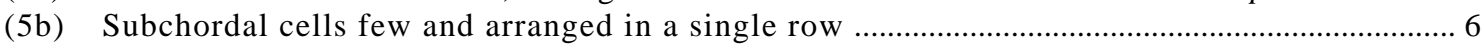

(6a) Left lobule of the stomach without caecum .......................................................................... 7

(6b) Left lobule of the stomach with caecum. Tail with approximately eight globular cells, arranged in two groups

Oikopleura cophocerca

(7a) One spindle-shaped cell .............................................................................. Oikopleura rufescens

(7b) Two spindle-shaped cell ................................................................................ Oikopleura dioica

(8a) Velum well developed. Eisen oikoplasts absent........................................ Oikopleura longicauda

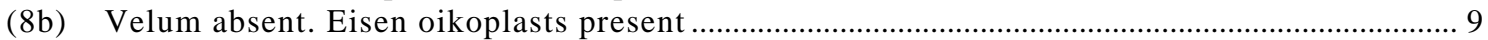

(9a) With large and well-developed postcardial caecum, posterior margin curved backwards ..........

.. Oikopleura fusiformis

(9b) Without postcardial caecum ........................................................................ Oikopleura gracilis

(10) Mouth with lobes. Tail wide and sharpened towards the distal end. The genital organs placed in the posterior part of the digestive nucleus: genus Fritillaria .................................................... 11

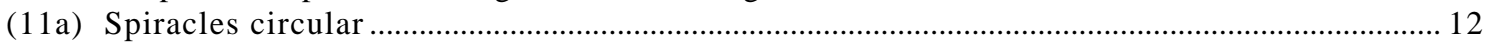

(11b) Spiracles oval, more or less elongated. Trunk oval. Ovary moniliform followed by a concaveshaped testis Fritillaria fraudax

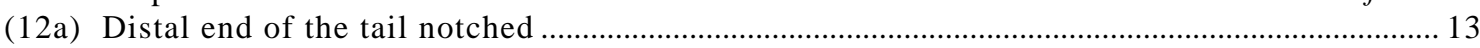

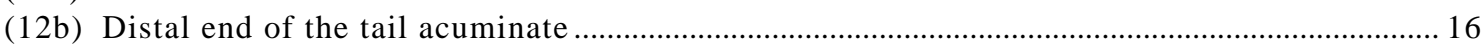

(13a) Tail with one amphichordal cell on each side of the notochord ...................... Fritillaria tenella

(13b) Tail with a couple of amphichordal cells on each side of the notochord.

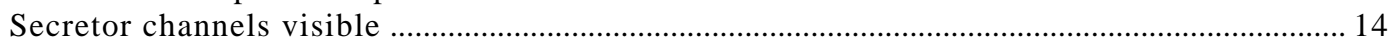

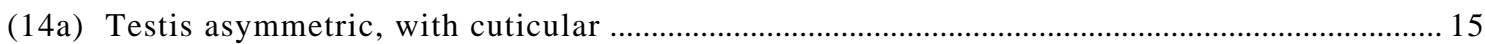

(14b) Testis trapezoidal, with laterally expanded lobules and without cuticular expansions. Ovary developed along the testicle

Fritillaria venusta

(15a) Asymmetric testis, r-shaped. Cuticular expansions long .................. Fritillaria pellucida typica

(15b) Asymmetric testis, Y-shaped. Cuticular expansions short ................ Fritillaria pellucida omani

(16a) Trunk elongated and narrows. Spherical ovary followed by a cylindrical testis

Fritillaria haplostoma

(16b) Trunk elongated, forming an angle that gives the aspect of a dorsal hump..... 